\title{
THE SEDIMENTATION RATE AND FRAGILITY OF HUMAN ERYTHROCYTES IN VITRO AFTER EXPOSURE TO LEAD CHLORIDE
}

\author{
BY \\ T. W. CLARKSON* and J. E. KENCH \\ From the Departments of Occupational Health and Chemical Pathology, University of Manchester
}

(RECEIVED FOR PUBLICATION NOVEMBER 1, 1957)

One important contributory factor in producing anaemia in lead poisoning in human subjects is undoubtedly the inhibition of the biosynthesis of haem in erythroid bone marrow cells (Eriksen, 1955). To what extent a haemolytic action of lead participates has been the subject of much experimental study.

McFadzean and Davis (1949) demonstrated more abundant stippled cells in the bone marrow of leadpoisoned guinea-pigs than in the peripheral circulation, such cells being rapidly and preferentially taken up by the spleen. The interpretation of the data was that punctate basophilic erythrocytes were abnormal both in haemoglobin content and physical structure as a consequence of damage by lead before the corpuscles were released from the haemopoietic site.

The peripheral action of lead has not been evaluated with certainty. Aub, Fairhall, Minot, and Reznikoff (1926) made extensive studies in vitro, mainly on washed red blood cells in phosphate-free Ringer solutions. The addition of small quantities of lead chloride caused increased mechanical fragility of the corpuscles which, however, became more resistant to hypotonic haemolysis. An increased mechanical fragility of the circulating corpuscles through contact with plasma lead was regarded as the essential feature of the anaemia of lead poisoning. Indirect evidence which supported this view has been reported more recently, namely, raised urobilinogen excretion in lead-poisoned guinea-pigs (Baikie, 1954) and coproporphyrinuria I in severely poisoned workmen (Kench, Lane, and Varley, 1952). The data in a recent investigation (Holeček and Pěničková, 1957) are unfortunately qualitative only.

*Present address : Department of Biochemistry, Rochester University, New York.
Aub and his colleagues postulated that blood lead was distributed between plasma inorganic phosphate and phosphate groups on the red blood corpuscular surface, now known to be largely dominated by such groups (Furchgott and Ponder, 1941). Lead in whole blood caused much less damage to the erythrocytes than in phosphate-free Ringer suspensions owing to the protection afforded by the plasma inorganic phosphate. Small quantities of lead added to whole blood remain in the plasma as colloidal lead phosphate, but with larger quantities relatively more lead would become bound to the erythrocytes. Changes in fragility were ascribed to the release of hydrochloric acid in the corpuscular surface layers by interaction of lead salt with inorganic phosphate groups. Certain aspects of this hypothesis have been discounted. Bischoff, Maxwell, Evans, and Nuzum (1928) observed that lead salts of weak acids, e.g., lead glycerophosphate, were equally productive of similar changes in the red blood cell although no mineral acid was released. Bambach, Kehoe, and Logan (1942) and Mortensen and Kellogg (1944) described a rapid removal of lead by the red cells even at low blood levels. Clarkson and Kench (1958) from kinetic studies of interaction of lead with human erythrocytes in vitro, have envisaged a process involving coagulation and flocculation of a peptized lead phosphate sol on the cellular membrane. No competitive inhibition of uptake of lead was observed with any of a number of potential competitors tested, including other metal ions, namely, $\mathrm{Cu}^{2+}, \mathrm{Hg}^{2+},\left(\mathrm{uO}_{2}\right)^{2+}$, and $\mathrm{Tl}^{4+}$. Chelating agents such as EDTA removed lead attached to erythrocytes only slowly in vitro, indicating that the metal was present in a practically unionized state.

The present investigation was undertaken to reexamine the behaviour of human erythrocytes following exposure to lead in vitro, in the light of 
the kinetic data and especially from the viewpoint of a modifying influence of inorganic phosphate.

\section{Experimental}

Materials.-Blood from healthy young men was collected from the antecubital vein into a $500 \mathrm{ml}$. lead-free bottle containing a $0.9 \%$ sodium chloride solution of $1 \mathrm{~g}$. glucose and anticoagulant (heparin or an ammonium potassium oxalate mixture $3 \mathrm{mg}$. per $100 \mathrm{ml}$. blood). The blood was examined immediately after collection or stored at $4^{\circ} \mathrm{C}$. and used within 48 hours.

The $\mathrm{NaCl}$ solutions used in this work were rendered lead free by passage through a column of sulphonated ion exchange resin, "Zeo-carb" 225 in the sodium cycle. Solutions in the Krebs Ringer bicarbonate mixture (Umbreit, Burris, and Stauffer, 1945) were deleaded in a similar way with the ion exchange column prepared in the appropriate cycle.

The apparatus was of " pyrex" glassware, which was cleaned with boiling nitric acid and then thoroughly washed with doubly distilled water. Where "pyrex" was not procurable, soda glass was coated with silicone "repelcote" $(2 \%$ solution of a methyl chlorosilane in carbon tetrachloride, Hopkin and Williams Ltd.) and cleaned with nitric acid.

\section{Methods}

Erythrocyte Sedimentation Rate.-Two millilitres from well below the top of a column of packed red blood cells obtained by centrifuging whole heparinized blood were suspended in $2.5 \mathrm{ml}$. oxalated plasma and various quantities of lead chloride in the range 0 to $50 \mu \mathrm{g}$. lead were added. The mixture was allowed to equilibrate during 20 minutes at $20^{\circ} \mathrm{C}$. Samples were removed for measurement of the sedimentation rate in Westergren tubes enclosed in a well-insulated glass tank maintained at $20 \pm 0 \cdot 1^{\circ} \mathrm{C}$.

A similar procedure was followed for equivalent suspensions of red blood cells in $0 \cdot 16 \mathrm{M} . \mathrm{NaCl}$ and in Krebs Ringer bicarbonate solution. Results are presented in Figs. 1 to 3.

Hypotonic Haemolysis Curves.-Lead chloride solution, $0.1 \mathrm{ml}$., was added to whole oxalated blood in a concentration equivalent to $11 \mu \mathrm{g}$. lead per ml. packed red blood cells, computed from the packed red cell volume as measured in Wintrobe tubes. The suspension was allowed to equilibrate during 30 minutes at $37^{\circ} \mathrm{C}$. Afterwards a sample was removed and added to plasma, also maintained at $37^{\circ} \mathrm{C}$., to give a final red blood cell suspension of $5 \%$ by volume. Of this suspension, $0.42 \mathrm{ml}$. was added to $3.6 \mathrm{ml}$. of hypotonic sodium chloride solution, the concentration of which was that required to bring the final volume $(4.02 \mathrm{ml}$.) to the desired tonicity. The hypotonic saline suspensions were incubated in a water-bath at $37^{\circ} \mathrm{C}$. for $30 \mathrm{~min}$. The tubes were then centrifuged and the supernatant removed so as to measure the haemoglobin concentration in a " unicam" spectrophotometer S.P. 500 at $540 \mathrm{~m} \mu$. The $100 \%$ lysis control tube was that containing $0.4 \mathrm{ml} .5 \%$ red cells added to $3.6 \mathrm{ml}$. doubly distilled water, and the degree of haemolysis in the other hypotonic saline solutions was expressed as directly proportional to the haemoglobin concentration in the supernatant solutions.

Observations were repeated on the specimen of blood allowed to stand in contact with lead for a further 24 hours at $37^{\circ} \mathrm{C}$. Whole blood to which no lead was added was employed as a control. A $50 \%$ by volume suspension of thrice-washed corpuscles in $0.16 \mathrm{M}$. $\mathrm{NaCl}$ was also studied as for whole blood. Results are presented in Figs. 4 to 6.

\section{Results}

The sedimentation curves show that whereas lead increases the erythrocyte sedimentation rate in saline (Fig. 1) the opposite is true in Krebs Ringer bicarbonate solution and in oxalated plasma (Figs 2 and 3). Differences may also be remarked between saline and plasma when considering hypotonic haemolysis. A definite resistance to haemolysis was observed when red blood cells in saline were exposed to lead for $30 \mathrm{~min}$. (Fig. 4) or for 24 hours (Fig. 5), but no such effect could be detected when the metal was added to whole blood (Fig. 6).

\section{Discussion}

Our observations on sedimentation rate and fragility of erythrocytes exposed to lead are in agreement in many respects with those of Aub and his colleagues (1926). Little damage was inflicted on the cells provided excess phosphate was present, either as in whole blood or in Krebs Ringer solution.

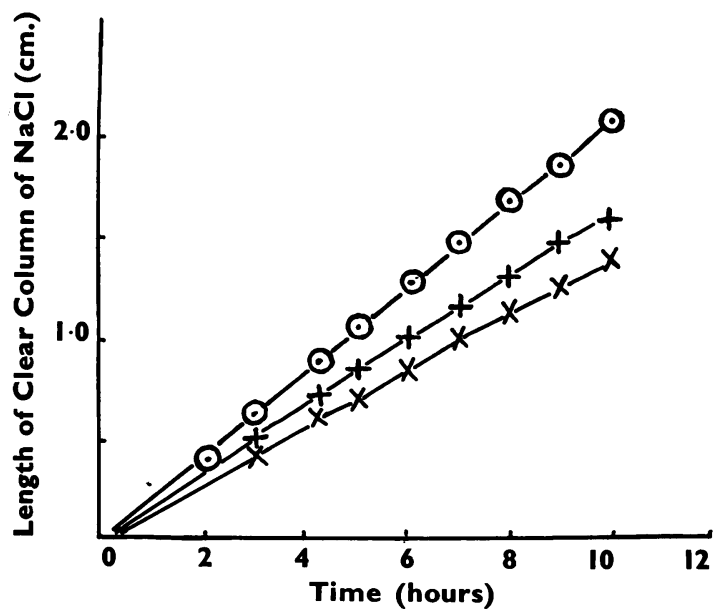

FIG. 1.-The sedimentation rate of red blood cells in saline suspension at $20^{\circ} \mathrm{C}$. after exposure for $20 \mathrm{~min}$, to various concentrations of lead chloride. A control curve for a saline suspension not exposed to lead is included. The suspension contained the equivalent of $2.5 \mathrm{ml}$. packed R.B.C. per $3 \mathrm{ml}$. saline.

$X-X$ control curve

$+\longrightarrow$ R.B.C. exposed to lead equivalent to $5 \mu \mathrm{g}$. per $\mathrm{ml}$. packed R.B.C.

$\odot-\bigcirc$ R.B.C. exposed to lead equivalent to $50 \mu \mathrm{g}$. per $\mathrm{ml}$ packed R.B.C. 


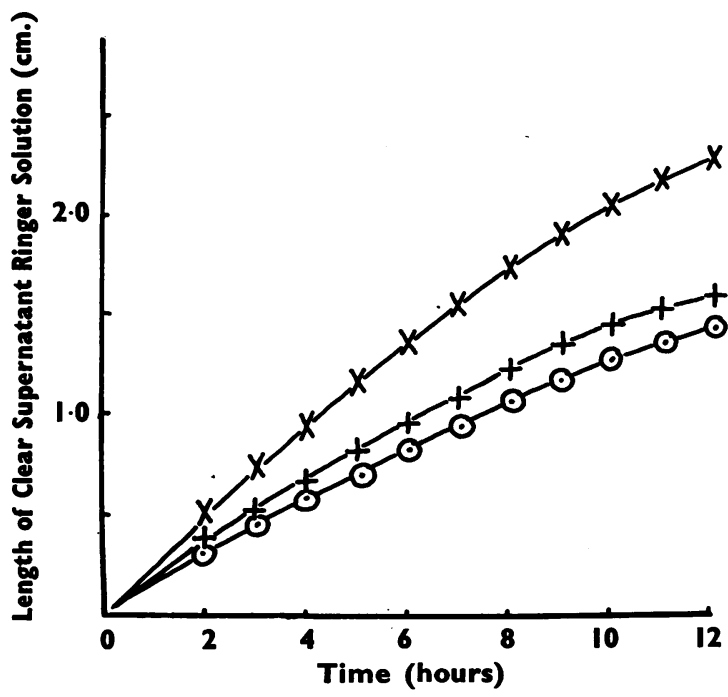

Fig. 2.-The sedimentation rate of red blood cells suspended in Krebs Ringer bicarbonate solution at $20^{\circ} \mathrm{C}$. after exposure for $20 \mathrm{~min}$. to various concentrations of lead chloride. A control curve for a similar suspension not exposed to lead is included. The suspension contained the equivalent of $2.5 \mathrm{ml}$. packed red cells per $3 \mathrm{ml}$. Krebs Ringer bicarbonate solution.

$X-X$ control curve
+- R.B.C. exposed to lead equivalent to $10 \mu \mathrm{g}$. per $\mathrm{ml}$ packed R.B.C.

$\circ-0$ R.B.C. exposed to lead equivalent to $50 \mu \mathrm{g}$. per $\mathrm{ml}$. packed R.B.C.

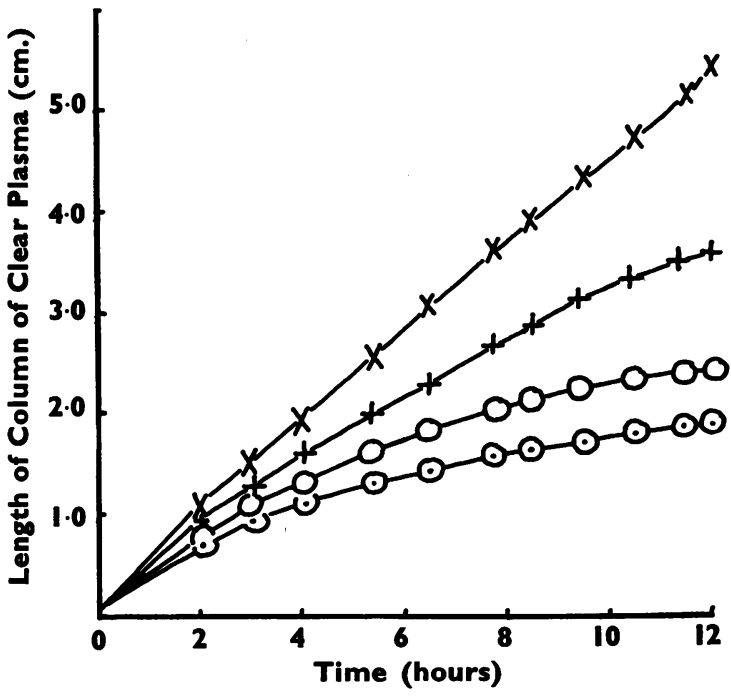

FIG. 3. - The sedimentation rate of red blood cells in whole oxalated blood at $20^{\circ} \mathrm{C}$. after exposure for $20 \mathrm{~min}$. to various concentrations of lead chloride. A control curve of whole blood not exposed to lead chloride is included. The whole blood used in the experiment contained the equivalent of $2.5 \mathrm{ml}$. packed red cells per $3 \mathrm{ml}$. plasma.

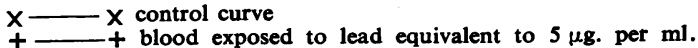
R.B.C.

0 - $O$ blood exposed to lead equivalent to $20 \mu \mathrm{g}$. per $\mathrm{ml}$. R.B.C.

0 blood exposed to lead equivalent to 30,40 , and 50 ug. per ml. R.B.C

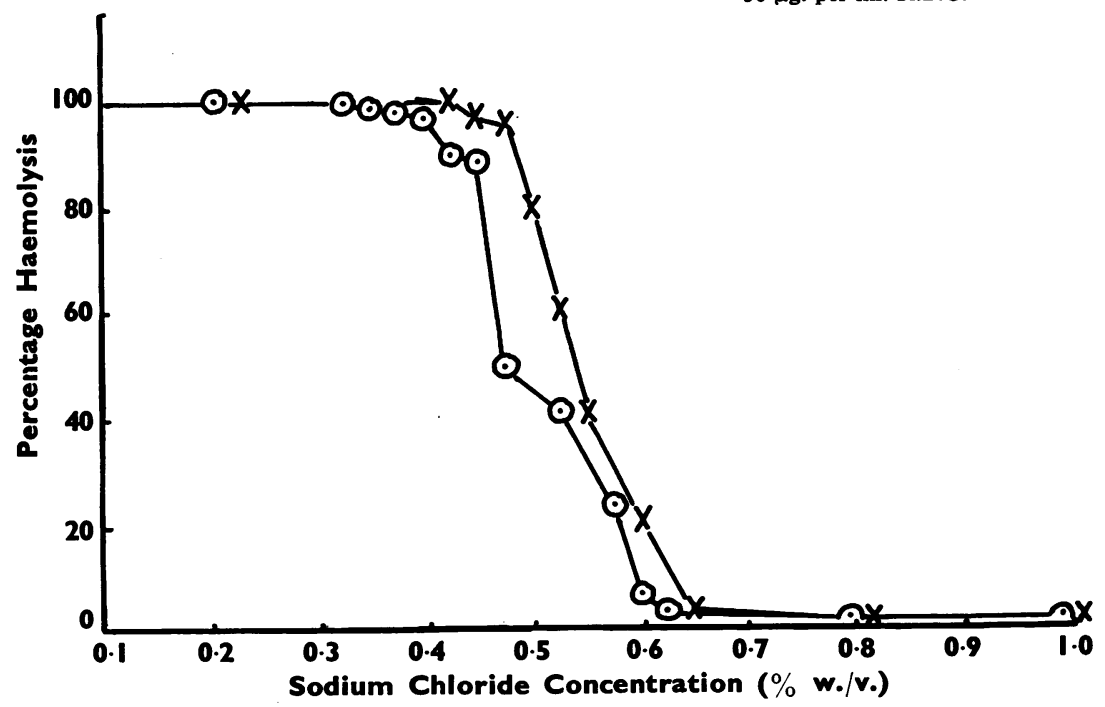

Fig. 4.-Hypotonic haemolysis at $37^{\circ} \mathrm{C}$. of a saline suspension of red blood cells exposed to lead chloride equivalent to $10 \mu \mathrm{g}$. lead per $\mathrm{ml}$. packed red cells for $30 \mathrm{~min}$. The suspension had been allowed to stand at $37^{\circ} \mathrm{C}$. for one hour before addition of lead. A control curve for a saline suspension without added lead stood for an identical time is included.

$X-X$ control curve 


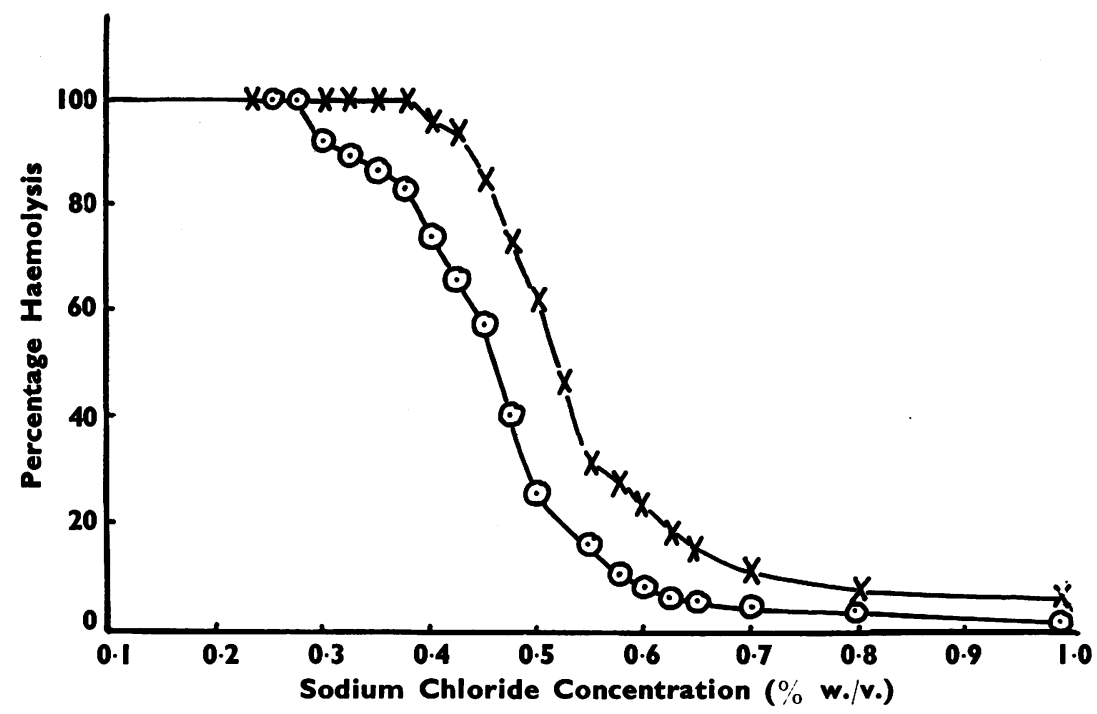

Fig. 5.-Hypotonic haemolysis at $37^{\circ} \mathrm{C}$. of a saline suspension of red blood cells exposed to lead chloride equivalent to $10 \mu \mathrm{g}$. lead per ml. packed red cells for $\mathbf{2 4} \mathrm{hr}$. The suspension had been allowed to stand at $37^{\circ} \mathrm{C}$. for one hour before addition of lead. A control curve for a saline suspension without added lead stood for an identical time is included.

$X-X$ control curve $0-0$ cells exposed to

This does not arise by inhibition of lead uptake, however, as postulated by Aub, but by a quite different mechanism. Clarkson and Kench (1958) have concluded from detailed kinetic studies that a peptized lead phosphate sol was first produced, which interacted on the cellular membrane to form a precipitate of lead phosphate even when the concentration of added lead was extremely small. The physical changes and behaviour of the erythrocytes can be better understood if the state of the added lead is considered. Many of the data are compatible with the concept of a lead phosphate sol carrying a charge dependent on the relative proportions of lead and phosphate ions present. In solutions containing excess phosphate, the lead sol would be negatively charged, and on attachment to the erythrocyte would raise the negative charge already present. Mutual repulsion of the corpuscles would be strengthened, and hence the rate of sedimentation diminished. In saline suspensions, especially of thrice-washed red blood cells, the concentration of free phosphate ions would be very low, and the net charge on the lead phosphate sol probably reversed. This would account for the more rapid corpuscular uptake of lead from such low phosphate media. Attachment to the corpuscles would partially neutralize the

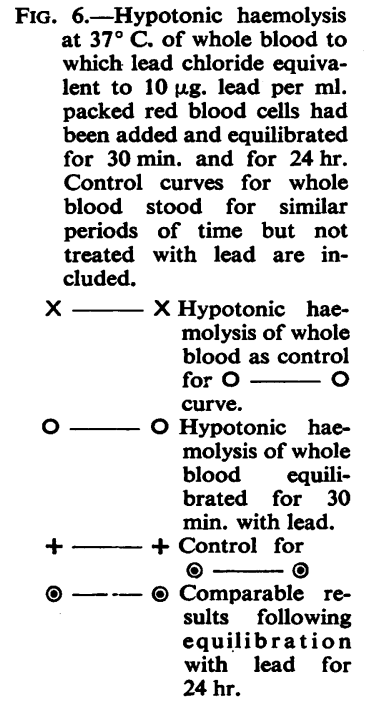

FIG. 6.-Hypotonic haemolysis which lead chloride equivalent to $10 \mu \mathrm{g}$. lead per $\mathrm{ml}$ packed red blood cells had pecuilibrated Con 30 min. and for $24 \mathrm{hr}$ blood stood for similar periods of time but not treated with lead are included. molysis of whole blood as control

Hypotonic haeblood equilibrated for 30 with lead. 0 equilibration $24 \mathrm{hr}$.

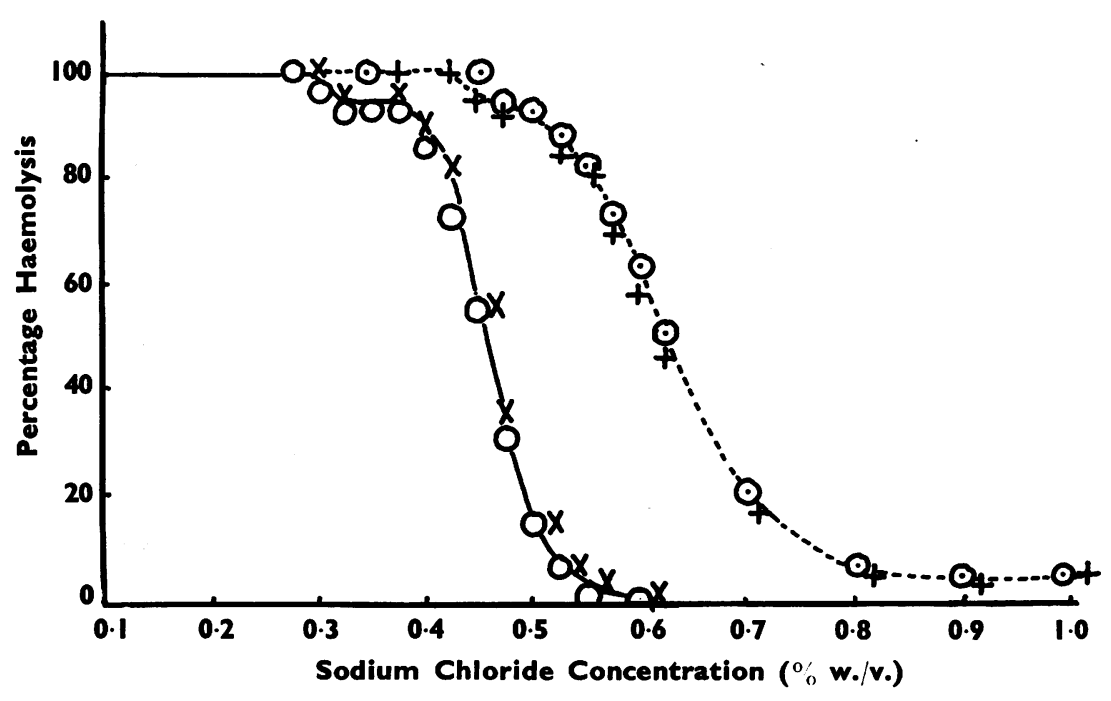


stabilizing negative surface charge, leading to augmented sedimentation rate. It is not at all clear why diminished osmotic fragility should be a consequence of this course of events. Direct inhibition by surface lead of anion and water transport across the corpuscular membrane is discounted by the low ionization of the metal complex. Complementary electron microscopical studies may help towards an understanding of this effect.

Our interpretation depends upon the direction and not on the magnitude of the effects of lead on the sedimentation rate of the erythrocytes: the lack of stoichiometry is evident in Fig. 3 where the rates in the presence of 30,40 , and $50 \mu \mathrm{g}$. $\mathrm{Pb}$. were indistinguishable from one another. The great difference between the sedimentation rates in $\mathrm{NaCl}$ and media containing phosphate (Krebs Ringer bicarbonate solution and whole blood) illustrates the importance of the phosphate groups present, and the changes produced by added lead must be interpreted in terms of the control. The contrasting effect of lead added to $\mathrm{NaCl}$ as compared with phosphate-containing media was observed consistently in several experiments. This phenomenon is not due merely to modification of the medium, since in every case the added lead is rapidly taken up by the corpuscles.

Our results suggest that the protective action of plasma and of other solutions containing excess phosphate is due to the approaching lead phosphate sol possessing a negative charge in such media and not to a prevention of lead uptake by the phosphate as suggested by earlier workers. It also seems unlikely that lead added to red cells in whole blood under conditions similar to the state in vivo will produce any detectable damage to the cell. One must conclude that the injury caused by lead to the red blood corpuscles-and evidence for increased haemolysis has been mentioned earlier in this paper -must occur during and be confined to formative stages in the bone marrow. Here occur intracellularly the enzymatic disturbances which result in restricted production of haem and probably punctate basophilia. Dialysis studies (Clarkson and Kench, 1958) have located intracellular lead incorporated presumably during haemopoiesis. Such lead, if biochemically active, would undoubtedly be in a form other than phosphate, since a psptized phosphate sol would not be available for reaction with essential groups in enzymes such as carboxylate, sulphydryl, and phosphate. How lead can enter the immature cells to produce these biochemical and morphological changes is a problem for future study.

\section{Summary}

A study is described of the interaction of lead with human erythrocytes as portrayed by the sedimentation rate and osmotic fragility.

Sedimentation rates were reduced for red blood cells exposed to lead in media containing excess phosphate, e.g., whole blood and Krebs Ringer bicarbonate solution. An increased sedimentation rate was observed in erythrocytes exposed to lead chloride in saline.

Little change in the osmotic fragility of red blood corpuscles was detectable when lead was added in the presence of excess phosphate, but in saline there was a marked increase in resistance to haemolysis in hypotonic saline.

It is concluded that in vivo plasma lead will cause only minimal changes in the fragility of circulating erythrocytes: all injurious effects (inhibition of haem synthesis and morphological abnormalities such as punctate basophilia) will have already been produced in precursor cells developing in the bone marrow.

Our thanks are due to Professor R. E. Lane for his continued interest in these investigations. We are indebted to Dr. R. L. Turner for helpful discussions and to Mr. H. V. Stevenson for technical assistance. We are grateful to the Medical Research Council who provided generous support for the work in a grant to one of us (T. W. C.) and in defraying research expenses.

\section{REFERENCES}

Aub, J. C., Fairhall, L. T., Minot, A. S., and Reznikoff, P. (1926). Lead Poisoning. Williams \& Wilkins, Baltimore.

Baikie, A. G. (1954). Blood, 9, 461.

Bambach, K., Kehoe, R. A., and Logan, M. A. (1942). J. Pharmacol., 76, 326 .

Bischoff, F., Maxwell, L. C., Evans, R. D., and Nuzum, F. R. (1928). Ibid., 34, 85.

Clarkson, T. W., and Kench, J. E. (1958). Biochem. J. In press.

Eriksen, L. (1955). Scand. J. clin. lab. Invest., 7, 80.

Furchgott, R. F., and Ponder, E. (1941). J. gen. Physiol., 24, 447. Holeček, V., and Pénicková, M. (1957). Brit. J. industr. Med., 14, 198.

Kench, J. E., Lane, R. E., and Varley, H. (1952). Brit. J. industr. Med., 9,133 .

McFadzean, A. J. S., and Davis, L. J. (1949). Quart. J. Med., 18, 57. Mortensen, R. A., and Kellogg, K. E. (1944). J. cell. comp. Physiol.,

Umbreit, W. W., Burris, R. H., and Stauffer, J. F. (1945). Manometric Techniques and Related Methods for the Study of Tissue
Metabolism, 2nd Ed., p. 119. Burgess Publishing Co. Minneapolis. 